\title{
ICТОРИЧНА БІОГРАФІСТИКА
}

УДК 821.161.2-1.09:791

\section{ІСТОРИЧНА КІНОДОКУМЕНТАЛІСТИКА МИКОЛИ ВІНГРАНОВСЬКОГО}

\author{
Ігор КОЛЯДА \\ Наиіональний педагогічний університет ім. М. П. Драгоманова, \\ кафедра навчання суспільних дисциплін і гендерної освіти, \\ вул. Освіти 6, 03037, Київ, Украӥна \\ e-mail: kolyada.i.a.1968@gmail.comDOI: \\ DOI: $10.15330 /$ gal.32.210-219 \\ ORCID: 0000-0002-3802-9082
}

\begin{abstract}
У статті в контексті біографії М. Вінграновського розкрито малодосліджений аспект його творчості - історичну кінодокументалістику. Вперше із залученням нового комплексу архівних джерел та матеріалів розкрито сторінки біографії мития, пов'язані з реалізацією проекту “кіноенциклопедії історї Украӥни”, проаналізовано творчі плани мития та причини успіхів і невдач, акцентовано увагу на національно-культурницькій складовій творчості видатного діяча шістдесятництва.
\end{abstract}

Ключові слова: шістдесятництво, кінодокументалістика, історична кінодокументалістика, кінотворчість, кіноенциклопедія історії Украӥни.

Трансформації, якими відзначені процеси державотворення в сучасній Україні потребують документальної фіксації. Документальне кіно - це, безумовно, бачення світу автором. Навіть якщо використовувати для зйомок лише камеру спостереження, яка фіксуватиме, хто заходить і виходить із приміщення, а потім самому відібрати кадри і змонтувати їх, отримуємо суб'єктивний погляд автора. Документальне кіно - це людина, іï світ. Вона - це нескінченність, iі пізнати неможливо. Документальне кіно - це історія, на тлі неймовірних місць та подій. Проблеми українського кіно, української документалістики потребують подальшого осмислення й аналізу. Висвітлення історії становлення кінодокументалістики незалежної України є суспільно важливою й науково значимою проблемою. Поважне місце у розвитку української кінодокументалістики належить М. Вінграновському. Висвітлення цієї грані таланту видатного митця $\epsilon$ актуальною проблемою, розкриття якої сприятиме подальшому розвитку української біографістики в цілому, створенню комплексної біографії талановитого діяча української культури, який став знаковою постаттю для історії культури України XX - початку ХХІ століття.

Наукова новизна нашого дослідження полягає у подальшому дослідженні нових аспектів націокультурної діяльності М. Вінграновського та створення комплексної біографії життя і творчої діяльності митця, залучаючи нові архівні джерела, зокрема фонди Центрального державного архіву-музею літератури і мистецтва України (ЦДМАМЛМ. Ф.1009.) та фонд "Укркінохроніки”, здійснено спробу проаналізувати вклад М. Вінграновського у розвиток української історичної кінодокументалістики.

Дослідженню різних аспектів біографії М. Вінграновського та його феномену присвячено роботи таких дослідників, як: А. Афоніна ${ }^{1}$, О. Безручко ${ }^{2,3,4}$, Ю. Гладир ${ }^{5}$, В. Доній ${ }^{6}$,

\footnotetext{
${ }^{1}$ Афоніна А. Режисер і поет. На екранах Украйни. 1969. 23 серп. С. 2.

2 Безручко О. Витоки творчої діяльності видатного українського кінематографіста і поета М. С. Вінграновського. Сучасне мистецтво. Вип. 12. Київ, 2016. С. 43-45.

${ }^{3}$ Безручко А. Грани киноискусства Н. С. Винграновского (к 80-летию со дня рождения). Пытинні мастаџтва знауства этналогї̈ і фалькларыстыкі. Вып. 22. Минск : Права экономка, 2017. 492 с.

${ }^{4}$ Безручко О. Геніальний український митець М. С. Вінграновський: між літературою і кінематографом. Національна ідентичність в мові $і$ культурі : збірник наукових праць / за заг. ред. А. Г. Гудманяна. О. Г. Шостак. Київ : Талком, 2017. 343 с.
} 
А. Добролежа ${ }^{7}$, Л. Дудюк ${ }^{8}$, М. Ільницький ${ }^{9}$ Д. Kiт $^{10}$, I. Коляда $^{11}$, В. Кондрашов ${ }^{12}$, Д. Кремінь ${ }^{13}$, С. Підопригора ${ }^{14}$, В. Савчак ${ }^{15}$, Л. Тарнашинська ${ }^{16,17}$, Н. Трефяк $^{18}$.

Здобуття Україною незалежності, крах радянської тоталітарної моделі розвитку на початку 90-х рр. XX ст. здавалося відкривали перед М. Вінграновським нові такі давно омріяні перспективи - реалізації своїх творчих мрій та планів, визначивши новий етап у його творчій та життєвій біографії. У ці роки одним із напрямків творчості митця стає історична кінодокументалістика.

Українська історія у творчому дискурсі Миколи Вінграновського займає, як слушно відзначає Т. Салига, якщо не домінуюче, то дуже суттєве місце. Митець якось наче й не помічав, що він увесь в історії, а вона у ньому ${ }^{19}$. У листі Б. Сушинського він пояснює як з'явилися його "Чотирнадцять столиць України”. “Це все є для мене дещо несподіваним... За фахом я не історик, написати історію України, як це, скажімо, зробили М. Грушевський, П. Дорошенко чи Н. Полонська-Василенко, справа надзвичайно важка, копітка i, окрім всеохопних знань, вимагає всього життя й терплячості. Мої ж “Короткі нариси з історії України” почалися 3 пропозиції редакції Народного календаря, отого відривного, по листочку календаря, що висить на стіні мало не в кожній хаті. Редакція запропонувала мені, на вибір, написати про когось або про щось із нашої минувшини. Така думка, очевидно, прийшла від ознайомлення 3 моїм романом "Северин Наливайко", що друкувався у журналі "Вітчизна" і який ось-ось має з’явитися у видавництві “Веселка”. На пропозицію редакції календаря я з приємністю згодився,

${ }^{5}$ Гладир Ю. Довженкіана Миколи Вінграновського. Наукові записки. Художся література $і$ кінематограф: проблеми інтерактивності. Серія : Філологічні науки. Кіровоград : РВВ КДПУ ім. В. Винниченка, 2012. Вип. 110.160 с.

${ }^{6}$ Доній В. С. Художня концепція ментальності українського народу (за романами М. Вінграновського “Северин Наливайко” та Л. Костенко “Берестечко”). Науковий вісник Миколаӥвського державного університету : зб. наук. праць. Миколаїв, 2007. Вип. 14. С. 84-88.

7 Добролежа А. Микола Вінграновський у спогадах, листах і кіно : до 70-річчя поета, кінореж., кіноактора Вітчизна. 2006. № 9/10. С. 128-134.

8 Дудюк Л. П. Історичні факти і художній вимисел в романі М. Вінграновського “Северин Наливайко”. Науковий вісник Миколаӥвського державного університету : зб. наук. праць. Миколаїв, 2007. Вип. 14. С. $135-142$.

${ }^{9}$ Ильницкий М. В современном - прошлое и будущее (Микола Винграновский). От поколения к поколению : Литературно-критические очерки и портреты / [пер. с укр.]. Москва : Советский писатель, 1984. C. 204-230.

${ }^{10}$ Кіт Д. Дорога до храму. Краєзнавчий альманах. 2003. Вип. 2. С. 53-58.

11 Коляда I. Роль Олександра Довженка ; педагога у формуванні творчої особистості Миколи Вінграновського. Вісник аграрної історії. № 23-24. Київ, 2018. 302 с.

12 Кондрашов В. В. “Кинематографические” шестидесятники: штрихи к литературным портретам Ивана Драча, Лины Костенко и Николая Винграновского. Гуманитарные научные исследования. 2013. № 5. URL: http://human.snauka.ru/2013/05/3208 (дата звернення: 10.01.2019).

${ }^{13}$ Кремінь Д. Історіософський контекст лірики Миколи Вінграновського. Науковий вісник Миколаӥвського державного університету : зб. наук. праць. Вип. 17 : Філологічні науки / ред. М. І. Майстренко та ін. Миколаїв : МДУ, 2008. С. 90-96.

14 Підопригора С. В. Фольклорна основа “химерних" елементів у історичному романі Миколи Вінграновського “Северин Наливайко”. Науковий вісник Миколаївського державного університету : зб. наук. праць. Миколаїв, 2007. Вип. 14. С. 108-112.

${ }_{15}^{15}$ Савчак В. Уроки великого майстра. Ленінська молодь. Львів. 11 лют. 1978.

16 Тарнашинська Л ..... I обертається з землею Україна. “Микола Вінграновський: Все на світі з людської душі”. Київ, 2006. С. 23.

${ }^{17}$ Тарнашинська Л. Вінграновський М.: “Все на світі з людської душі” : біобібліографічний нарис. Серія : “Шістдесятництво: профілі на тілі покоління”. Київ, 2006. 106 с.

18 Трефяк Н. І. Синтезування епічного, ліричного та кінематографічного первнів у індивідуальній стильовій “манері” прози Миколи Вінграновського. Науковий вісник Волинського національного університету імені Лесі Украӥнки. 2009. № 14. С. 80-85.

${ }^{19}$ Салига Т. Микола Вінграновський сьогодні, або Дискурс української історії в його поезії. День. 2010. № 137.4 серп. С. 7 . 


\section{2}

та замість того, аби написати “про когось або про щось” з нашої історії, сів і спробував

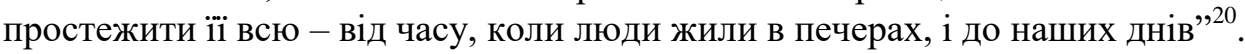

"Письменник виробляв власну поетичну культуру, що виростала на його культурі почуттєвій, естетичній, родовій, ментальній, - зазначає сучасна дослідниця Л. Тарнашинська, остання була повною мірою обумовлена тими етнопсихологічними чинниками, які й формують українську ментальність, специфіку поетичного мислення. Син степу і моря, він зумів синтезувати в своєму поетичному баченні всю Україну - від просоленого Сиваша до найменшої річечки" 21 . Сюди пасує додати уточнює Т. Салига, що митець зумів синтезувати уроки та досвід трагічної і героїчної української історії, зіставляючи її з сучасністю: “Ти бачиш: попід часом, попід віком, // Де все не спить і прагне та болить, // Сумний мій задум ходить біля вікон, // Шаблюкою у шибку шебертить. // ... // ... // Минає все, лиш наше не минає, // Одним займаємось, що ставимо свічки, // Та гордо плачемо, та "Заповіт” співаєм, // Співаєм тяжко так, що наче залюбки. // Та всмак їмо могутніми зубами, // Цілуємось могутньо, як бійці, // І в кого на душі синці або рубці, // То аж тоді - це не в ім'я забави... // ...Попід небом, листом і соломою, // Під землею в вічність завглибки, // Синьою безоднею солоною // Козаки ладнають байдаки. // Там Самійло Кішка й Сагайдачний, // Там Небаба чорний і гіркий, // I правиці рапаногарячі // Козаків над лугом у віки. // Вони ідуть мені в обличчя // В тій небрехливій глибині, // Де воля волю тихо кличе, // Де море стогне і кигиче, // І зиче дещо і мені...,22.

Творча ідея зняти 44 документальні фільми із серії “Чотирнадцять столиць України" позначена продовженням справи свого вчителя О. Довженка. Чи не довженківська мета проступає в цьому його великому, хоч так і не реалізованому задумі: “Коли я це зроблю, світ зможе познайомитися з Україною не з газетних публікацій і не з Чорнобиля, а з їі глибинних протягів, чесно, точно і зримо зроблених мовою кіно" 23. "М. Вінграновський свого часу мав задум зняти цикл документальних фільмів, присвячених історії України (більше 40)", але встиг зняти лише восьму частину із запланованої серії” - зазначає мистецтвознавець А. Кульчицкий ${ }^{24}$. Як згадував згодом сам М. Вінграновський поштовхом до цього задуму стало його разом із кіноактрисою Оленою Пархоменко та режисером Станіславом Клименко участь у “першому за всі роки та часи українському кінофестивалі”, що проходив на Пряшівщині, Закарпатська область. Митців приймали тепло: вони демонстрували фільми, проводили творчі зустрічі, М. Вінграновський, на прохання місцевих жителів, навіть виступив зі своїми поезіями. "Рідні люди" згадуватиме він їх у своїх листах до друзів ${ }^{25}$. У листі до українського поета та журналіста в еміграції Володимира Біляїва він писав: “А їх на Пряшівщині 40 тисяч, і вони, їхній корінь 3 діда-прапрадіда там. І ось: українське радіо вони не чують, хіба що по вечорах, і то дуже тихо; українського телебачення у них нема, хоч це від Ужгорода - рукою подати! Мадяри, поляки, що там живуть, - все від своїх країн мають! А наші - ніц! Одні у селі мені навіть казали: "Ми знаємо, що ми українці, але про Україну ми лише чули і не знаємо, де вона!..”

“... Одне слово, Володимире Івановичу, тут на Пряшівщині, я вперше в своєму житті відчув, що у мене $є$ держава! Нарешті! ... Я, очевидно, з вересня місяця поїду у Пряшів, зніму для них, русинів, про них фільм: вони просили. Вони дуже просили"26. В іншому листі до Володимира Біляїва він уточнює: "Пригадуєте, що Вам писав про Пряшівщину і що в мене виник задум зняти на екрані історію України. Всю історію нашого народу - від сарматів і скіфів по сьогоднішній день ... I для цього фільму-читанки, фільму-букваря про історію нашої нації кінематографічній зоровій оповіді від найдавніших часів я, здається, й знайшов точну форму -

\footnotetext{
${ }^{20}$ Салига Т. Микола Вінграновський сьогодні, або Дискурс української історії в його поезії... С. 7.

21 Тарнашинська Л. ... I обертається з землею Україна... С. 23.

22 Салига Т. Микола Вінграновський сьогодні, або Дискурс української історії в його поезії... С. 7.

${ }^{23}$ Вінграновський М. Все на світі : $з$ людської душі. Вечірній Київ. 1999. 13 січ. С. 6.

${ }^{24}$ Кульчицький А. 212 спогадів з Миколою Вінграновським. Фрагменти спогадів про великого Українця. Літературна Украӥна. 2011. 4 серп. № 29 (5408). С. 10-11.

${ }^{25}$ Маршал Вінграновський. Книга про поета (спогади, есеї, листи, інтервюю) / передм., упорядкув.

П. Вольвач. Київ : Ярославів Вал, 2011. С. 347.

${ }^{26}$ Там само.
} 
“П’ятнадцять столиць України”. А саме: Київ (докиївська і Київська Русь), Галич, Холм, Хортиця, Чигирин, Гадяч, Глухів, Батурин, знову Київ (революція - Петлюра, Грушевський, Винниченко), Вінниця, Кам'янець-Подільський, Львів, Гуляйполе (Махно), Харків, Хуст, Рахів (УПА) і знову Київ з президентом Кравчуком. Ось такий мій задум",27.

Творчий проект підтримав Микола Жулинський (у той час радник президента 3 питань культури), надавши йому офіційного листа, в якому зобов'язували органи місцевої влади всіляко сприяти роботі М. Вінграновського. Але відразу приступити до створення "кіноенциклопедіï” про історію України, сповнений амбіцій, режисер не зміг. Його активної участі вимагав фільм про О. Довженка, зйомки якого, на той момент, тягнулись уже кілька років. Документальний фільм готували до 100-річчя від дня народження Олександра Петровича, яке припадало на 1994 р. Матеріалом для сценарію та закадрового тексту для фільму став “Щоденник" О. Довженка. "Я хочу в цьому фільмі дати Довженка, яким він був, а не яким ми його уявляємо в силу своїх скороминущих пристрастей і подій. А він, сам Довженко, його “Щоденник” дають мені для цього повну можливість. І я, будь-що, а це я зроблю, і вже почав робити”, - виправдовував свою зайнятість М. Вінграновський, у листі до В. Біляїва від 4 червня 1992 p. $^{28}$. Виробництво фільму “Довженко. Щоденник 1941-1945 роки” було завершено в 1993 році, і відразу по його релізі, М. Вінграновський приступив до роботи над першим фільмом із запланованого циклу. У процесі роботи задум розрісся до 20 кінострічок.

У серпні 1992 р. на київської студії документальних кінофільмів "Укркінохроніка", хоча на той час, М. Вінграновський ще офіційно працював на Київській кіностудії імені О. Довженка, розпочались зйомки документальних фільмів. Першим фільмом із цієї серії став "Батурин столиця гетьмана Івана Мазепи”. Планувалося випустити його двома частинами. Сценарій було написано за мотивами історичного нарису I. Борщака та Р. Мартеля "Мазепа". Головний редактор картини, А. Комарницький схвально відгукнувся і про культурний потенціал картини, і про мистецький талант М. Вінграновського, але перед тим, як фільм було запущено у виробництво, висловив ряд критичних зауважень. Зокрема, в недолік майбутньому проекту ставилась надмірна героїзація образу I. Мазепи: “Буде неправильно оминати чи притушовувати цей трагізм протиріч особистості Мазепи, на підставі лише одних його намірів, а не фактів результатів його діяльності, представляти його однозначно історично позитивною особою", - характеризував фільм А. Комарницький ${ }^{29}$. Крім цього, було зроблено зауваження і щодо змістового контенту самого кінофільму. Поставивши в назву фільму “Батурин”, М. Вінграновський фактично не розкриває історію самого міста, особливості його функціонування в період правління І. Мазепи, значення Батурина для свого регіону, не розкривається також його етнічний склад чи економічний стан розвитку. Назва міста слугує лише приводом для розкриття образу І. Мазепи. 3 метою уникнення відмічених редакторами огріхів, до знімальної групи був залучений історичний консультант Євген Лук'яненко ${ }^{30}$. Виробництво фільму було завершено весною 1993 року. Фільм "Батурин - столиця гетьмана Івана Мазепи” було здано в 3 частинах 15 червня того ж року ${ }^{31}$.

Свій творчий проект М. Вінграновський вирішив втілювати у київській студії документальних кінофільмів "Укркінохроніка", будучи прийнятим на посаду кінорежисера вищої категорії, після звільнення у травні 1993 р. з Київської кіностудії імені О. Довженка.

Продовженням “кінематографічної читанки” М. Вінграновського став фільм “Чигирин столиця гетьмана Богдана Хмельницького", при зйомках якого він виступив у якості сценариста, режисера та диктора закадрового голосу. Своїм документальним фільмом, Микола Степанович прагнув познайомити широку українську громадськість 3 подіями Національновизвольної війни українського народу під проводом Богдана Хмельницького 1648-1657 pp.

\footnotetext{
${ }^{27}$ Маршал Вінграновський. Книга про поета (спогади, есеї, листи, інтерв’ю) ... С. 350.

${ }^{28}$ Там само. С. 349.

${ }^{29}$ Центральний державний архів-музей літератури і мистецтва України (далі - ЦДАМЛМ). Ф. 1009 :

Українська студія хронікально-документальних фільмів. Оп. 1. Спр. № 1790. Арк. 40.

${ }^{30}$ Там само. Арк. 60.

${ }^{31}$ Там само. Арк. 63
} 


\section{4}

Особливий акцент митець робив на звільненні українського народу від польсько-шляхетського гніту, отриманні ним довгоочікуваної можливості творити власну державу. "Не було вікна в українській хаті, куди б не заглянула воля" - описував Микола Степанович своє бачення тогочасних суспільних настроїв у сценарії кінофільму ${ }^{32}$. Головним редактором фільму знову був А. Комарницький. I незмінним полишилось і зауваження щодо сценарію фільму: недостатність висвітлення соціально-економічного життя міста Чигирин в період Національно-визвольної війни 1648-1657 рр. Але це не стало на заваді виробництву фільму, і в тому ж таки 1993 р. його зйомки та монтаж були вже фактично завершені, але виникла інша проблема - відсутність необхідного фінансування для завершального етапу зйомок. Директор студії "Укркінохроніка" О. Мухамедова звернулася по допомогу до тогочасного заступника міністра культури І. Лимаря. Його просили викупити коштом державного бюджету вже майже готовий фільм "Чигирин столиця гетьмана Б. Хмельницького”, і забезпечити державне фінансування зйомки наступного фільму “Чигирин - столиця гетьмана Івана Виговського" 33. У зв'язку зі скрутним фінансовим становищем в країні, міністерство культури не змогло профінансувати останній проект, але перший фільм було викуплено у зв'язку із заходами присвяченими відзначенню на державному рівні 400-річчя від народження Богдана Хмельницького.

Дирекція київської студії документальних кінофільмів "Укркінохроніка" не полишала спроб продовжити роботу над проектом і забезпечення підтримки його на державному рівні. У зв'язку із цим директор “Укркінохроніки” О. Мухамедова надіслала офіційні листи-прохання міністру культури І. Дзюбі та народному депутату й режисеру Лесю Танюку. У листах, студія просила профінансувати дві наступних роботи "Галич - столиця князя Данила Галицького" та про національно-визвольні змагання українського народу на західноукраїнських землях в 1944 1952 pp. $^{34}$. Директор підкреслювала особливе громадсько-політичне значення серії та просила виділити кошти у сумі 100 мільйонів карбованців. Профінансувати обидві картини не вдалося, але "Галич - столиця князя Данила Галицького" все-таки отримав "зелене світло". Фільм було затверджено, але 3 рекомендацією залучити професійного історика. Зйомки відбувалися у Львівській та Івано-Франківській областях ${ }^{35}$. I у вересні 1993 року виробництво фільму було завершено. М. Вінграновський повернувся в Київ, але з надією відразу вирушити назад на Західну Україну, щоб почати зйомки наступного фільму “Українська Повстанська Армія, 1942 1952 pp". На той момент, він уже написав і надіслав на затвердження сценарій майбутнього фільму, редакторській групі "Укркінохроніки”, де той був зареєстрований під назвою "Степан Бандера". Ї̈ редактор А. Комарницький відразу відмітив, що “автор-режисер писав цю довідку для себе, не вдаючись до установлених прийомів художнього розкриття теми”. Студія зобов'язувала режисера обов'язково залучити до роботи над фільмом професійного історика ${ }^{36}$. Про подальші свої творчі плани М. Вінграновський писав у листі від 2 вересня 1993 року до США В. Біляєву: “Фільм про Байду Вишневецького я, Володимире Івановичу, відклав на пізніші часи, бо поки кіностудія виділила мені певний кошторис, то я взявся за "Данила" та за "УПА". Я щойно приїхав із Західної України... де знімав "Данила Галицького"... Починаю новий фільм під назвою "Українська Повстанська Армія, 1942-1952 роки"... Взявся за “Данила" і за "УПА". Особливо за "УПА". Бо в Україні цю нашу національну армію, завдяки радянській пропаганді, або ж проклинають, або ж ніхто про неї не чув і не знає. Через те майбутнє моє кіно про УПА - це моя принципова позиція, як би не дивилася на неї частина нашого народу Східної і Центральної України. В цьому фільмі я викладуся увесь, і він має бути одним з найголовніших із тих двадцяти серій про національну історію України, що я задумав"37. Про важливість для М. Вінграновського фільму "Українська Повстанська Армія, 1942-1952 роки” свідчить і той факт, що також долучається до процесу пошуку джерел фінан-

\footnotetext{
${ }^{32}$ ЦДАМЛМ. Ф. 1009. Оп. 1 Спр. № 1816. Арк. 7.

${ }^{33}$ Там само. Спр. № 1790. Арк. 57.

34 Там само. Спр. № 1796. Арк. 1, 2.

${ }^{35}$ Маршал Вінграновський. Книга про поета (спогади, есеї, листи, інтерв’ю)... С. 352.

${ }^{36}$ ЦДАМЛМ. Ф. 1009. Оп. 1. Спр. № 1816. Арк. 7.

${ }^{37}$ Кур’єр Кривбасу. 2005. № 182. С. 89.
} 
сування зйомок. Пробує використати свої особисті зв'язки й стосунки. Він пише листи міністру культури І. Дзюбі, народним депутатам Л. Танюку та М. Жулинському, прагнучи забезпечити державне фінансування проекту, вважаючи, що якщо “уряд його не підтримає, то його чекає повна катастрофа, ${ }^{, 38}$.

Відсутність належного фінансування змушує митця на деякий час припинити реалізацію кінопроекту. 31993 по 1997 рр. він переносить реалізації ідеї кіноенциклопедії з історії України зі сфери кінематографії у сферу літератури. У ці роки він опікується виходом роману “Северин Наливайко”, над яким він працював шість років (з 1986 р. по 1992 р.), але друк якого постійно відкладався". У України”. Автор передмови до неї, історик Богдан Сушинський, вважав їх цілком логічним, по черговості твором, до якого М. Вінграновський йшов через документальні історичні кінофільми, роман "Северин Наливайко", через поетичне осмислення фактів української історії ${ }^{40}$. У своїх "Нарисах по історії України" він розповів про Трипілля, Київ, Галич, Холм, Хортицю, Чигирин, Гадяч, Батурин, Немирів, Бендери, Глухів, Львів, Харків, Хуст.

"Чотирнадцять столиць України" стали ще одним значним успіхом М. Вінграновського періоду незалежної України, після роману “Северин Наливайко”. Крім виходу однією книгою, вони ще й були передруковані всіма 25 обласними газетами, які, на той час, були сильно зацікавлені в національно-культурному матеріалі. Публікації були безгонорарними, але М. Вінграновський почував себе “морально задоволеним, як ніколи"

У 1997 р. митець знову повертається до реалізації проекту “кіноенциклопедії України”. Повернутися до процесу створення документального серіалу про історію України вдалося у 1997 р. Йому вдається залучити до реалізації проекту кошти приватного інвестора. М. Вінграновський розпочав зйомки документального фільму "Гетьман Сагайдачний". Нове джерело фінансування було незвичним для Миколи Степановича і він постійно переживав, аби інвестор “не охолов". Ще однією складністю при зйомках фільму став брак полотен живопису, які б мали забезпечити візуальний картинний ряд фільму. Полотен присвячених періоду гетьманування Петра Сагайдачного не було у загальному доступі. Цю проблему митцю вдалось вирішити завдяки фондам київських музеїв, в яких вдалося віднайти книги та альбоми живопису, які були конфісковані у приватних колекціонерів органами державної безпеки в 1930-х роках. Виробництво фільму було досить повільним і зайняло два роки. Лише у квітні 1999 р. зйомки фільму було завершено ${ }^{42}$.

Наступними кінокартинами, які запланував М. Вінграновський мали стати "Пилип Орлик” і “Петро Дорошенко”. Відсутність державного фінансування проекту змусило Миколу Степановича вдатися до неординарних кроків. Було створено офіційний фонд "14 столиць незалежної України”. У 1998 р., він звернувся по допомогу до українців діаспори у світі. Було розіслано 298 листів, але це залишилось “пустим благанням". “Прийшло мені 1100 доларів від священика Красевича, з Канади 500 доларів, 250 від невідомої жінки з США, 50 доларів від невідомого чоловіка з Австралії, 10 доларів від старенької жінки з Нової Зеландії і 300 доларів від Ганни Черінь - спасибі їй за добре серце"43. Невдача 3 пошуком коштів серед українців діаспори не зупинила творця. Він шукає можливість про фінансувати зйомки фільму "Пилип Орлик" через фонд Сороса, але отримав відмову - "Чотирнадцять столиць України" проект державний, значить фінансуватися повинен державою ${ }^{44}$.

Проблема подальшого фінансування проекту стала ключовою при його реалізації. М. Вінграновський встиг створити лише: "Хортиця - столиця Запорізької Січі" (1993), “Чигирин - столиця гетьмана Богдана Хмельницького” (1994), “Батурин - столиця гетьмана Івана

\footnotetext{
${ }^{38}$ Маршал Вінграновський. Книга про поета (спогади, есеї, листи, інтерв'ю)... С. 353.

${ }^{39}$ Там само. С. 356.

${ }^{40}$ Там само. С. 357.

41 Там само. С. 358

42 Там само. С. 362.

43 Там само. С. 362.

44 Там само. С. 363.
} 
216

Мазепи” (1994), “Галич - столиця князя Данила Галицького” (1995), “Дмитро Вишневецький Байда" (1993) та "Гетьман Сагайдачний” (1999)

Кінопошуки М. Вінграновського суттєво вплинуло на його стилістику як поета, так прозаїка. Особливість співвідношення часового й просторового параметрів у кіно виражається наступним чином: екранний час не $\epsilon$ адекватним реальному, він більш спресований, i, навіть більше того, час у кадрі тече тим швидше, чим насиченіша дія. Кіно зображує дію, котра вже “відбулася" у минулому, проте через особливості сприйняття зображення в темному просторі кінозалу глядач інтерпретує побачене як таке, що відбувається в даний момент, “тут і зараз”, завдяки чому в нього виникає глибокий емоційний зв'язок з тим чи тим персонажем. Відбувається це через безпосередність сприйняття оком елементів зображення, адже саме зорова система $є$ домінантною й пов'язує між собою інші сигнальні системи ${ }^{46}$. При аналізі творчості Миколи Вінграновського спосіб ліричної організації художнього світу прози простежується як на рівні образності (асоціативних утворень), так і на сюжетно-композиційному рівні (зокрема суб'єктивізації оповідності). Кінематографія як особливий вид мистецтва відіграє важливу функцію у творчості автора. Як зауважує Лариса Брюховецька: “об'єднує кіно й літературу можливість часо-просторової побудови оповіді, здатність розкривати ліричне начало й характер героя через його емоційний стан”,47. На думку дослідниці Лариси Брюховецької: “принципова відмінність між літературою та кіно криється в характері сприйняття і впливу цих видів творчості”. Поєднання ж в одному тексті епічного та кінематографічного начал значно розширює горизонт рецепції. Перегляд кінострічки відображає тривимірну сутність і кіномистецтва, і художнього твору, оскільки події, що відбуваються на екрані, сприймаються в кількох часових площинах одночасно: $з$ погляду реципієнта під час читання художнього твору, з боку читача як глядача, який сприймає емоційно наснажену фабулу фільму, 3 позиції глядача (зокрема батьків головного героя) під час перегляду кінострічки. Таким чином, сприймання однієї і тієї ж події твору з кількох ракурсів одночасно свідчить про споріднення епосу та кінематографіï ${ }^{4}$. Так, у прозі митця, зауважує Н. Трефяк, можна відшукати діалектичну єдність різних художніх начал: "Із взаємодії різних видів мистецтв виникає тематичне розмаїття творів Миколи Вінграновського. Специфіка стильової манери митця вирізняється завдяки діалектичній єдності різних мистецьких начал. Синтезування ліричного та кінематографічного первнів виокремлюються в способах ліризації прози та використанні кінематографічних прийомів моделювання художньої дійсності. Ліричні ознаки прозових текстів письменника часто виявляються не осібно, а поєднуються 3 кінематографічними прийомами. Процеси взаємовпливу видів мистецтва простежуються на прикладі різних творів автора й диференціюються в одному тексті прози митця, що засвідчує оригінальність індивідуальної стильової манери Миколи Вінграновського - прозаїка" 49 . Зорові й слухові ефекти, калейдоскопічність, мінливість, монтування кадрів, чіткий темпоритм - ці кінематографічні якості органічні для прози М. Вінграновського. Така бінарність, на думку російського літературознавця В. Кондрашова, вирізняє і поетичну творчість М. Вінграновського ${ }^{50}$. Нероздільну єдність кінотворчості митця 3 поетичною не раз відмічали і сучасники: “Бувало, що у неділю, із Одеси до Миколи приїздили знайомі поети, переважно молодь. Смакували молодим вином, читали вірші. Свої вірші, щасливо купаючись у поглядах колег, читав і Микола Вінграновський. Саме у цей час він написав цикл

\footnotetext{
${ }^{45}$ Вінграновський М. Хто і що для мене незалежність. День. № 159. 2010. C. 10. URL: https://day.kyiv.ua /uk/article/kultura/hto-i-shcho-dlya-mene-nezalezhnist-ukrayini (дата звернення:10.01.2019).

${ }^{46}$ Степанченко О. Кінопоетика у творах Миколи Вінграновського. Літературознавчі студіі. 2013. Вип. 39 (2). С. 395. URL: http://nbuv.gov.ua/UJRN/Lits_2013_39\%282\%29_55 (дата звернення: 11.01.2019).

47 Брюховецька Л. І. Література і кіно: проблеми взаємин : літературно-критичний нарис. Київ : Радян. письм., 1988. С. 66.

48 Там само. С. 67.

49 Трефяк Н. І. Синтезування епічного, ліричного та кінематографічного первнів у індивідуальній стильовій “манері” прози Миколи Вінграновського. Науковий вісник Волинського національного університету імені Лесі Украӥнки. 2009. № 14. С. 84.

${ }^{50}$ Кондрашов В. В. “Кинематографические” шестидесятники: штрихи к литературным портретам Ивана Драча, Лины Костенко и Николая Винграновского...
} 
поезій “У Холодній балці" та “Гайавату”. Але як не дивно, саме у цю пору повної цілодобової занятості на кіномайданчику і режисерської напруги поет Вінграновський написав ряд поезій, що свідчили про повноту його свободи та стихію його вільнолюбивої натури"

"Вінграновський-поет впливає на Вінграновського-режисера, але і його кінорежисерський професіоналізм має свої “виходи” як на поетичну творчість, так і на прозу”, - зазначає про його творчість науковець Тарас Салига. Разом з тим, дослідники зазначають, що, на жаль, у кінематографії поет не зміг у всій повноті виявити всю глибину свого таланту. Як і сам говорив, великою мірою через тоталітарну епоху ${ }^{52}$ " "Візуальне кіномистецтво, очевидно, не могло “вмістити” всю степову широку й рвійну натуру М. Вінграновського - і потреба вербального, словесного самовираження, коли у рядок, строфу можна вкласти так багато почуттів, зробила його неперевершеним поетом такого високого мистецького рівня, що ним могла би пишатися будь-яка національна література", - зазначає Л. Тарнашинська ${ }^{53}$

Таким чином, історична кінодокументалістика, незважаючи на незавершеність окремих проектів, виявила ще одну із рис феномену М. Вінграновського, засвідчивши високий ступінь його національної самосвідомості й стійкості, вірності ідеалам шістдесятництва та прагнення, незважаючи на суперечливості суспільно-політичних процесів “лихих 90-х рр.”, відсутності національноцентричних орієнтирів у тогочасному політикуму незалежної України, весь свій талант митця присвятити справі відродження національної культури та історичної пам'яті українців, подоланню інертності та інфантилізму, “духовного рабства” українського народу, сформованих радянською системою як моделі життя й створити “кіно енциклопедія історії України".

\title{
HISTORICAL CINEMA DOCUMENTALIST M. VINHRANOVSKYI
}

\author{
Igor KOLIADA \\ National Pedagogical University of M. P. Drahomanov, \\ Department of Social Studies and Gender Education, \\ Osvity St. 6, 03037, Kyiv, Ukraine \\ e-mail: kolyada.i.a.1968@gmail.comdoi
}

\begin{abstract}
Summary
The main idea of the article is to elucidation the contribution of the outstanding artist M. Vinhranovskyi to the development of Ukrainian cinema documentation.The disclosure of the actual problem will contribute to the further development of Ukrainian biography in general and the creation of a comprehensive biography of a talented figure of Ukrainian culture, which was a significant figure for the history of Ukraine from the 20-th to the beginning of the 21th century.

In the article Igor Kolyada "Historical documentary of M. Vinhranovskyi" in the context of M. Vinhranovskyi biography is related little investigated aspect of his work - historical film documentary.The author covers the stages of the project of M. Vinhranovsky's "Fourteen Capitals of Ukraine" from the conception of the idea to the embodiment of the creative idea.

For the first time, with the involvement of a new complex of archival sources and materials, the pages of artist's biography related to the implementation of the project "Cinema Encyclopedia of Ukrainian History".

The process of creation of the project's cinemas and the reasons for successes and failures accompanying the artist during the implementation of his creative ideas are discussed.The creative plans and plans of the artist are analyzed. That made it possible to reveal the national-cultural component of the work of a prominent figure of the sixties.

Historical documentary in the life of $M$. Vinhranovskyi, despite the incompleteness of the projects, gave an opportunity to highlight the ideals and to testify to the high degree of his national consciousness and stability, the loyalty to the ideals of the sixties and the desire to devote his entire talent to reviving the national culture and

\footnotetext{
${ }^{51}$ Добролежа А. Микола Вінграновський у спогадах, листах і кіно : до 70-річчя поета, кінореж., кіноактора... С. 128-134.

${ }^{52}$ Гладир Ю. Довженкіана Миколи Вінграновського... С. 41.

${ }^{53}$ Тарнашинська Л. “Вінграновський М. Все на світі з людської душі” : біобібліографічний нарис. [Серія

“Шістдесятництво: профілі на тілі покоління”]. Київ, 2006. С. 5.
} 
historical memory of Ukrainians, overcoming inertia and infantilism, "spiritual slavery" of the Ukrainian people, formed by the Soviet system as a model of life and create "the film encyclopedia of history of Ukraine".

Keywords: sixties, film documentary, historical documentary film, cinema-making, cinema encyclopedia of Ukrainian history.

\section{REFERENCES}

Afonina A. Rezhyser i poet. Na ekranakh Ukrainy. 1969. 23 serp. [in Ukrainian].

Bezruchko O. Vytoky tvorchoi diialnosti vydatnoho ukrainskoho kinematohrafista i poeta M. S. Vinhranovskoho. Suchasne mystetstvo. Kyiv, 2016. Vyp. 12. [in Ukrainian].

Bezruchko A. Hrany kynoyskusstva N. S.Vinhranovskoho (k 80-letyiu so dnia rozhdenyia). Pytannia mystatstvaznaustva, etnolohii i folklorystyky. Vyp. 22. Minsk : Prava ekonomika, 2017. [in Belorus].

Bezruchko O. Henialnyi ukrainskyi mytets M. S. Vinhranovskyi: mizh literaturoiu i kinematohrafom. Natsionalna identychnist v movi i kulturi : zbirnyk naukovykh prats / za zah. red. A. H. Hudmaniana. O. H. Shostak. Kyiv : Talkom, 2017. [in Ukrainian].

Bezruchko O. V. Tvorcha i mystetsko-nastavnytska diialnist $\mathrm{v}$ Ukraini diiachiv teatru i kino : monohrafiia. Kyiv : Vydav. tsentr KNUKiM, 2017. T. 1. [in Ukrainian].

Briukhovetska L. I. Literatura i kino: problemy vzaiemyn : literaturno-krytychnyi narys. Kyiv : Radian. pysm., 1988. [in Ukrainian].

Vinhranovskyi M. Vybrani tvory : u 3 t. T.3. Ternopil : Bohdan, 2004. [in Ukrainian].

Vinhranovskyi M. Khto i shcho dlia mene nezalezhnist. Hazeta “Den”. 2010. № 159. URL: https://day.kyiv.ua/uk/article/kultura/hto-i-shcho-dlya-mene-nezalezhnist-ukrayini.

Vinhranovskyi M. Vse na sviti - z liudskoi dushi. Vechirnii Kyiv. 1999. 13 sichnia. [in Ukrainian].

Handzii O. "Protiahom piaty rokiv u Moskvi ne promovyv zhodnoho slova rosiiskoiu movoiu" // zh.

Kraina. № 436. 28.08.2018. URL: https://gazeta.ua/articles/history-journal/_protyagom-pyati-rokiv-u-moskvine-promoviv-zhodnogo-slova-rosijskoyu-movoyu].

Hladyr Yu. Dovzhenkiana Mykoly Vinhranovskoho. Naukovi zapysky. Khudozhnia literatura i kinematohraf: problemy interaktyvnosti. Vyp. 110. Seriia : Filolohichni nauky. Kirovohrad : RVV KDPU im. V. Vynnychenka, 2012. [in Ukrainian].

Dobrolezha A. Mykola Vinhranovskyi u spohadakh, lystakh i kino : do 70-richchia poeta, kinorezh., kinoaktora. Vitchyzna. 2006. № 9/10. [in Ukrainian].

Donii V. S. Khudozhnia kontseptsiia mentalnosti ukrainskoho narodu (za romanamy M. Vinhranovskoho "Severyn Nalyvaiko" ta L. Kostenko "Berestechko"). Naukovyi visnyk Mykolaivskoho derzhavnoho universytetu : zb. nauk. prats. Mykolaiv, 2007. Vyp. 14. [in Ukrainian].

Dudiuk L. P. Istorychni fakty i khudozhnii vymysel v romani M. Vinhranovskoho "Severyn Nalyvaiko". Naukovyi visnyk Mykolaivskoho derzhavnoho universytetu : zb. nauk. prats. Mykolaiv, 2007. Vyp. 14. [in Ukrainian].

Ylnytskyi M. V sovremennom - proshloe y budushchee (Mykola Vynhranovskyi). Ot pokolenyia k pokolenyiu: Lyteraturno-krytycheskye ocherky y portrety [per. s ukr.]. Moskva : Sovetskyi pysatel, 1984. [in Russia].

Kit D. Doroha do khramu. Kraieznavchyi almanakh. 2003. Vyp. 2. [in Ukrainian].

Koliada I. Rol Oleksandra Dovzhenka - pedahoha u formuvanni tvorchoi osobystosti Mykoly Vinhranovskoho. Visnyk ahrarnoi istorii. Kyiv, 2018. № 23-24. [in Ukrainian].

Kondrashov V. V. "Kynematohrafycheske" shestydesiatnyky: shtrykhy k lyteraturnym portretam Yvana Dracha, Lyny Kostenko y Nykolaia Vynhranovskoho. Humanytarne nauchne yssledovanyia. 2013. № 5. URL: http://human.snauka.ru /2013/05/3208.

Kremin D. Istoriosofskyi kontekst liryky Mykoly Vinhranovskoho. Naukovyi visnyk Mykolaivskoho derzhavnoho universytetu : zb. nauk. prats. Vyp. 17 : Filolohichni nauky / red. M. I. Maistrenko ta in. Mykolaiv : MDU, 2008. [in Ukrainian].

Kulchytskyi A. 212 spohadiv z Mykoloiu Vinhranovskym. Frahmenty spohadiv pro velykoho Ukraintsia. Literaturna Ukraina. 2011.4 serpnia. № 29 (5408). [in Ukrainian].

Kurier Kryvbasu. 2005. № 182. [in Ukrainian].

Marshal Vinhranovskyi. Knyha pro poeta (spohady, esei, lysty, interviu) / peredm., uporiadkuv. P. Volvach. Kyiv : Yaroslaviv Val, 2011. 480 s. : il. [in Ukrainian].

Pidopryhora S. V. Folklorna osnova "khymernykh" elementiv u istorychnomu romani Mykoly Vinhranovskoho "Severyn Nalyvaiko". Naukovyi visnyk Mykolaivskoho derzhavnoho universytetu : zb. nauk. prats. Mykolaiv, 2007. Vyp. 14. [in Ukrainian].

Savchak V. Uroky velykoho maistra. Leninska molod. Lviv. 11 liutoho. 1978. [in Ukrainian]. 
Salyha T. Mykola Vinhranovskyi sohodni, abo Dyskurs ukrainskoi istorii v yoho poezii. Den. 2010. № 137. 4 serp. [in Ukrainian].

Stepanchenko O. Kinopoetyka u tvo rakh Mykoly Vinhranovskoho. Literaturoznavchi studii. 2013. Vyp. 39 (2). URL: http://nbuv.gov.ua/UJRN/Lits_2013_39\%282\%29_55.

Tarnashynska L I obertaietsia z zemleiu Ukraina. "Mykola Vinhranovskyi: Vse na sviti z liudskoi dushi”. Kyiv, 2006. [in Ukrainian].

Tarnashynska L. Vinhranovskyi M.: "Vse na sviti z liudskoi dushi”: biobibliohrafichnyi narys. [Seria "Shistdesiatnytstvo: profili na tili pokolinnia"]. Kyiv, 2006. [in Ukrainian].

Trefiak N.I. Syntezuvannia epichnoho, lirychnoho ta kinematohrafichnoho pervniv u indyvidualnii stylovii “maneri” prozy Mykoly Vinhranovskoho. Naukovyi visnyk Volynskoho natsionalnoho universytetu imeni Lesi Ukrainky. 2009. № 14. [in Ukrainian].

Tsentralnyi derzhavnyi arkhiv-muzei literatury i mystetstva Ukrainy. F. 1009 : Ukrainska studiia khronikalno-dokumentalnykh filmiv. Op. 1. Spr. № 1790. № 1796, № 1816, № 1811. 